\title{
Perkembangan Busana Adat Kepura Masyarakat Hindu Bali Dalam Era Globalisasi
}

Oleh

\author{
Ni Made Merlina Dwi Heriani (1704071013), I Putu Putrayana Wardana \\ Merlina_dewi205@gmail.com, putra.yana@undiksha.ac.id
}

\section{PENDAHULUAN}

Dewasa ini globalisasi sangat mempengaruhi zaman. Segala aspek menjadi berubah akibat dari arus globalisasi. Termasuk gaya hidup yang suka kebarat-baratan, mulai dari sikap, bicara, maupun dalam berbusana. Salah satu perubahan yang paling mencolok adalah soal penampilan (gaya pakaian). Gaya pakaian menjadi salah satu hal yang sangat mempengaruhi kepribadian seseorang di era globalisasi saat ini.

Tekanan globalisasi dewasa ini memang membawa dampak terjadinya pergeseran etika dalam berbusana adat ke Pura oleh masyarakat Hindu di Bali. Banyak masyarakat Bali yang kurang memahami dan juga ada yang tidak mau memahami tentang etika dalam berpakaian ke Pura. Banyak dari meraka terutama kaum perempuan yang memakai model baju kebaya (baju atasan yang sering dikenakan para wanita dalam persembahyangan ke Pura) yang kurang sesuai. Pada dasarnya berbusana tentu akan lebih baik jika disesuaikan dengan aktifitas / kegiatan yang akan dilakukan. Wanita sering kita jumpai mengenakan kebaya dengan bahan transparan dengan kain bawahan (kamen) bagian depan hanya beberapa $\mathrm{cm}$ dibawah lutut untuk melakukan persembahyangan. Kita seharusnya mengetahui bahwa pikiran setiap manusia tentu tidak sama, ada yang berpikir positif bahwa itulah trend mode masa kini. Tapi ada yang berpikiran negatif tentu tidak sedikit, inilah permasalahanya bagi orang yang mempunyai pikiran negatif, paling tidak busana terbuka akan mempengaruhi kesucian pikiran umat lain yang melihatnya.

Hal ini bisa terjadi karena pola pikir masyarakat. Mereka tidak mengerti akan makna dari busana adat Bali tersebut. Untuk itu agar tidak terus-menerus keliru, perlu adanya pemberitahuan kepada masyarakat secara umum tentang tatwa dalam berbusana adat Bali. Sehingga masyarakat menjadi lebih paham dang mengerti makna-makna yang terkandung dalam busana adat kepura. Jadi berpakaian ke pura itu di harapkan pakaian yang bisa menumbuhkan rasa nyaman baik yang memakai maupun yang melihat, menumbuhkan rasa kesucian, dan mengandung kesederhanaan. 
Warnanya pun akan lebih baik yang berwarna tidak ngejreng, karena pakaian bisa menumbuhkan kesucian pikiran.

Sebagai masyarakat Hindu Bali sepatutnya mempelajari, memahami dan juga melakasakan etika dalam berpakaian untuk persembahyangan ke Pura. Pikiranlah yang utama mengantarkan bhakti kita kehadapan Ida Shang Hyang Widhi Wasa. Dan apabila hanya ingin mengikuti trend dan mode pakaian yang dikenakan bisa menggagu konsentrasi, tentu saja itu akan membuat terganggunya situasi persembahyangan yang khusyuk.

Dengan berpakaian rapi, nyaman untuk digunakan dan tidak mengganggu penglihatan orang lain serta, dengan tidak melupakan unsur-unsur filosofis. Berpakaian itu akan jauh lebih baik daripada memakai pakaian transparan dan memakai kamen cukup tinggi hingga memperlihatkan paha. Pada akhirnya kembali kepada pemakai busana tersebut apa kata hati nurani (atmanasthuti)nya. Pantaskan sebuah trend busana tersebut dipakai untuk melakukan yadnya atau persembahyangan ?

Tulisan ini akan membahas hal-hal terkait etika berbusana ke tempat suci atau Pura. Adapun yang dibahas dalam tulisan ini antara lain:

1) Perkembangan Busana adat ke Pura masyarakat Bali

2) Penyebab dan Dampak Perubahan Gaya busana adat kepura.

\section{Perkembangan busana adat ke pura masyarakat Bali.}

Pakaian atau busana dikatakan sebagai suatu benda kebudayaan yang sangat penting untuk hampir semua suku bangsa di dunia. Saat ini banyak masyarakat Hindu yang menggunakan trend kebaya, entah apa yang mereka pikirkan. Dari hal tersebut membuat suatu gagasan menguhubungkan generasi intelek untuk menciptakan budaya ajeg Bali melalui cara berpakaian adat ke pura. Mengingat berpakaian adat ke pura merupakan ciri khas dari Provinsi Bali umumnya, memang terlihat anggun jika seseorang ke pura dengan pakaian sedemikian rupa dan menggunakan aksesoris yang berlebihan. Namun ada baiknya jika seseorang pergi ke pura berniat untuk menghadapkan diri pada Tuhan Yang Maha Esa. Tidak menggunakan pakaian bersih dan sopan serta sesuai dengan tattwa yang ada dalam tatanan agama dan budaya.

Pada zaman dahulu masyarakat Hindu Bali belum mengenal istilah baju kebaya namun mereka hanya menggunakan kamen saja. Dengan berjalanya waktu masyarakat mulai mengenal baju kebaya pada tahun 1945 . 
Masyarakat saat itu memakai baju kebaya yang sopan tentunya tidak menor. Seperti contoh gambar di bawah ini:

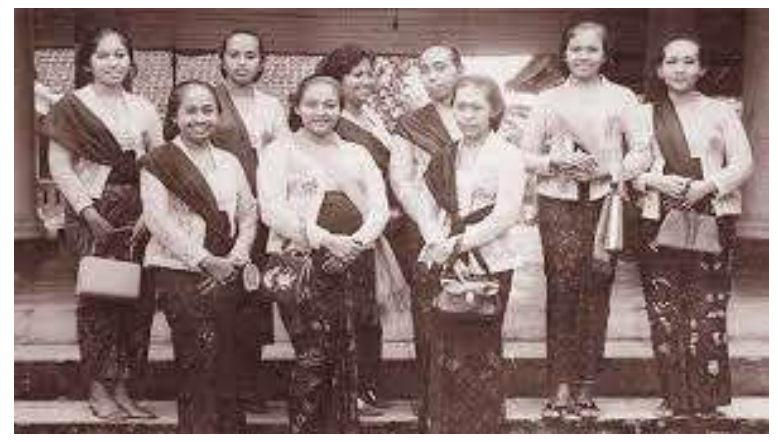

Gambar 1.1 Tradisi Busana Adat Ke Pura Zaman Dulu (www.google.com, diakses pada tanggal 10 Desember 2017)

Pada zaman sekarang ini kurangnya minat masyarakat Hindu Bali khususnya dari kalangan dehe (gadis) untuk memakai tata rias rambut model sanggul, termasuk menatanya dengan model pepusungan, juga amat jarang ditemukan. Umumnya kalangan wanitanya, lebih banyak menata rambutnya dengan cara membiarkan rambutnya terurai (megambahan), baik dengan potongan rambut pendek ataupun rambut panjang. Mereka juga biasanya menggunakan berbagai jenis ikatan di bagian belakang seperti gelang karet, ada juga yang menggunakan pita pengikat atau bando dengan variasi hiasan warna-warni. Sedangkan untuk kalangan prianya, dalam tata rias rambut, mereka cenderung tampil apa adanya tanpa sentuhan penataan salon kecantikan. Hanya saja karena terpengaruh model punk para pria yang menyisir rambutnya dengan model acak-acakan. Pada kalangan gadis juga banyak menggunakan kebaya yang lenganya pendek dan kamen yang pendek. Selain baju lenganya pendek terkadang model leher baju kebaya nya tidak sopan, seperti contoh gambar di bawah ini:

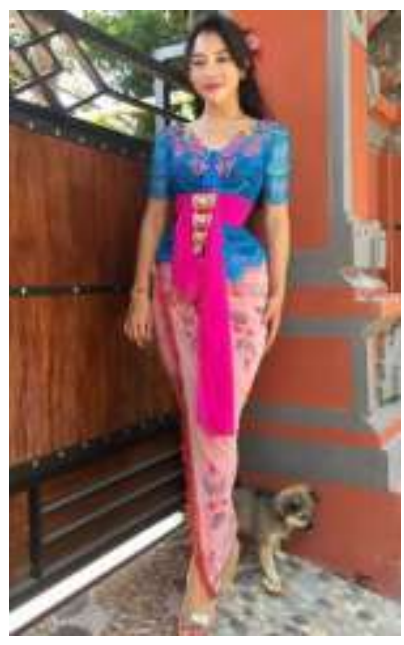


Gambar 1.2 Tradisi Busana Adat Ke Pura Di Era Globalisasi (www.google.com, diakses pada tanggal 10 Desember 2017)

Perkembangan busana adat masyarakat Hindu Bali pada zaman dahulu dengan zaman sekarang sangatlah berbeda. Perubahan zaman di era globalisasi ini membuat masyarakat selalu ingin mengikuti model (tren) yang sedang terkenal di media social. Kurangnya kesadaran masyarakat Hindu Bali dengan tata karma berbusana adat ke pura mengakibatkan banyaknya larangan-larangan yang dilakukan dan yang tidak pantas dipakai menjadi layak dipakaidan tentunya tidak sesuai dengan pakem. Pakaian yang baik dan benar dan tentunya sesuai dengan pakem akan memperlihatkan sifat dan ke takwaan kita terhadap Ida Sang Hyang Widhi Wasa. Seperti gambar di bawah ini

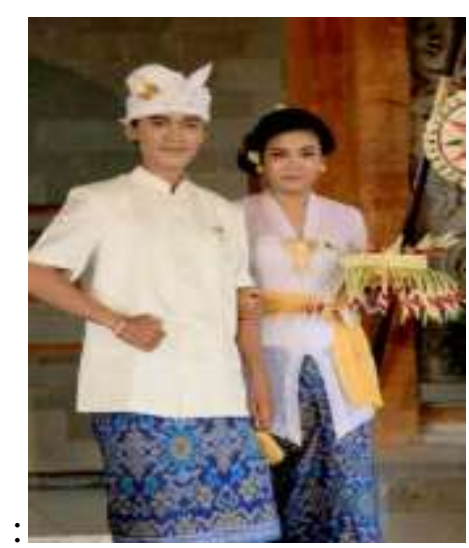

Gambar 1.3 Tradisi Busana Adat Ke Pura Sesuai Dengan Pakem (www.google.com, diakses pada tanggal 10 Desember 2017)

\section{Penyebab dan Dampak Perubahan Gaya busana adat kepura.}

Mantra (1996 : 1-2) mengemukakan, Globalisasi merupakan gejala yang tak dapat dihindarkan, tetapi sekaligus juga membuka kesempatan yang luas. Globalisasi telah membawa kemajuan besar dan perubahan-perubahan mendasar dalam kehidupan masyarakat Bali, khususnya umat Hindu yaitu terjadinya benturan kultur. Dalam konteks fenomena berpenampilan dalam berbusana adat kepura bagi umat Hindu.

Selama ini, banyak cara berpakaian busana adat ke pura yang tidak sesuai dengan pakem. Penyimpangan yang dilakukan terhadap berbusana ke pura ini tentunya dapat berpengaruh negatif. Dewa Putu Metayana, salah satu tim juri mengatakan, masyarakat sekarang boleh mengikuti perkembangan mode berpakaian namun hanya dilaksanakan dalam upacara resepsi atau menghadiri upacara perkawinan. Untuk berpakaian ke pura memang tidak ada 
aturan baku. Namun, sembahyang ke pura tentu harus berpakaian sopan dan tidak berpakaian embus pandang. Tidak hanya berpakaian, mulai dari penataan rambut harus rapi. Sedangkan untuk pakaian brokat yang sekarang mengalami banyak modifokasi hendaknya hanya dipakai saat pesta.

Adapun penyebab dari perubahan trend busana adat kepura bagi umat Hindu adalah :

- Banyaknya selebritis dan para model memakai bahan-bahan budaya bali yang dipakai sampel model atau desain terbaru untuk dimodifikasi.

- Dari adanya modifikasi yang dipakai model atau selebretis menjadi banyak yang ditiru oleh umat agama Hindu untuk busana kepura biar lebih modern.

- Adanya kombinasi atau perpaduan model busana barat dan busana local yang menjadi trend terbaru dalam berbusana.

- Berkembangnya pariwisata bali terutama orang-orang suka dengan budaya dan busana bali sehingga banyak menjadi barang dagangan untuk para tusisturis yang dating kebali.

- Berkembangnya trend (Fashion) busana-busana modern dari luar yang dapat mempengaruhi busana adat kepura sehingga dilihat menjadi lebih modis.

- Banyaknya umat Hindu (para $\mathrm{ABG)}$ ) yang mengikuti perkembangan fashion/trend terbaru dari berbagai gaya busana. Seperti kebaya, kamen dan pakaian lainnya.

Adapun dampak yang terjadi bagi umat hindu dari adanya perubahan seni berbusana diera globalisasi antara lain :

- Kurangnya kesadaran terhadap tatwa atau filosofi yang terkandung dari symbol-simbol busana adat kepura umat Hindu.

- Adanya penyimpangan etika dalam berbusana, seperti banyak busana contohnya : kebaya yang tarnsfaran dan pemakaian kamen terlalu tinggi (diatas lutut).

- Adanya pikiran-pikiran kotor dipura yang diakibatkan pakaian yang kurang sopan terutama bagi laki-laki yang tidak bisa mengontrol diri melihat busana yang tranfaran dan terlalu vulgar.

- Mengganggu kenyamanan saat sembahyang, dari bahan yang terlalu bervariasi dan gaya yang sedikit ketat. 
- Adanya persaingan busana dikalangan ibu-ibu yang lagi sembahyang akibat berkembangnya terus fashion atau model-model terbaru, sehingga dapat menimbulkan kesenjangan dan merasa jengah dalam berbusana.

\section{PENUTUP}

Mantra (1996 : 1-2) mengemukakan, Globalisasi merupakan gejala yang tak dapat dihindarkan, tetapi sekaligus juga membuka kesempatan yang luas. Globalisasi telah membawa kemajuan besar dan perubahan-perubahan mendasar dalam kehidupan masyarakat Bali, khususnya umat Hindu yaitu terjadinya benturan kultur. Dalam konteks fenomena berpenampilan dalam berbusana adat kepura bagi umat Hindu.

Sebagai masyarakat Hindu Bali sepatutnya mempelajari, memahami dan juga melakasakan etika dalam berpakaian untuk persembahyangan ke Pura. Pikiranlah yang utama mengantarkan bhakti kita kehadapan Ida Shang Hyang Widhi Wasa. Dan apabila hanya ingin mengikuti trend dan mode pakaian yang dikenakan bisa menggagu konsentrasi ,tentu saja itu akan membuat terganggunya situasi persembahyangan yang khusyuk.

\section{REFRENSI}

Dokumentasi sendiri tahun 2017

http://acaryawasu.blogspot.com/2012/11/tatwa-busana-adat-bali-makna ( diakses pada tanggal 15 Desember 2017) 
Acarya Pustaka, Vol.5,No.1, Juni 2018 
Acarya Pustaka, Vol.5,No.1, Juni 2018 